\title{
PENGARUH PERUBAHAN TINGKAT SUKU BUNGA BANK INDONESIA DAN PERUBAHAN NILAI TUKAR RUPIAH PADA US DOLLAR TERHADAP HARGA SAHAM-SAHAM LQ45 DI BURSA EFEK INDONESIA
}

\author{
Eni Puji Astuti ${ }^{1)}$ \& Rika Ardila ${ }^{2)}$ \\ 1,2) dosen dan mahasiwa universitas pamulang, email : dosen 00807@unpam.ac.id \& \\ anisa.sasmitha@gmail.com
}

\section{ARTICLES}

INFORMATION

ABSTRACT

JURNAL SEKURITAS

(Saham, Ekonomi, Keuangan dan Investasi )

Vol.2, No.3, Mei 2019

Halaman : 65-82

(c) LPPM \& Prodi Manajemen

UNVERSITAS PAMULANG

ISSN (online) : 2581-2777

ISSN (print) : :2581-2696

\section{Keyword :}

Sharia Bank, ROA, CAR, NPF, FDR, and BOPO

JEL. classification :

C33, G20, G23, N65

\section{Contact Author :}

PRODI MANAJEMEN UNPAM

JL.Surya Kencana No.1 Pamulang

Tangerang Selatan - Banten

Telp. (021) 7412566, Fax (021) 7412491

Email :

jurnalfinance.unpam@gmail.com
Tujuan Penelitian Untuk mengetahui pengaruh perubahan antara tingkat suku bunga bank Indonesia dan nilai tukar rupiah pada US Dollar terhadap harga saham - saham LQ45 di Bursa Efek Indonesia Tahun 2009 - 2015 secara simultan.

Populasi yang digunakan dalam penelitian ini adalah seluruh perusahaan yang sahamnya tergabung dalam indeks LQ45 di BEI selama periode penelitian 2009 sampai dengan 2015. Sampel pada penelitian ini adalah perusahaan yang sahamnya tergabung dalam indeks LQ45 di BEI yang dipilih dengan metode purposive sampling. Kriteria pemilihan sampel penelitian yaitu perusahaan yang aktif tercatat / terdaftar sebanyak empat belas (14) kali secara berturut - turut di Indeks LQ45 selama periode penelitian 2009 - 2015 jumlah sampel yang masuk kriteria penelitian adalah sebanyak 20 perusahaan yang terdaftar pada indeks LQ45. Metode analisis yang digunakan dalam penelitian ini adalah menggunakan analisis statistik melalui pendekatan Uji Asumsi Klasik, Uji Regresi Linier Berganda, Uji Koefisien Korelasi, Uji Koefisien Determinasi, Uji Parsial T dan Uji Simultan $\mathrm{F}$ dan selanjutnya akan dianalisis hasil regresi tersebut.

Hasil penelitian menunjukan bahwa Suku Bunga Bank Indonesia dan nilai tukar rupiah pada US Dollar secara parsial tidak mempunyai pengaruh signifikan terhadap Harga Saham - saham LQ45 Nilai Tukar Rupiah pada US Dollar secara parsial tidak mempunyai pengaruh signifikan terhadap Harga Saham - saham LQ45 Suku Bunga Bank Indonesia dan Nilai Tukar Rupiah pada US Dollar secara simultan bersama - sama tidak mempunyai pengaruh signifikan terhadap Harga Saham - saham LQ45 di Bursa Efek Indonesia selama periode 2009 sampai dengan 2015. 


\section{A. Pendahuluan}

Sejak terjadinya krisis moneter pada tahun 1997 dunia bisnis terutama dalam sektor perusahaan telah mengalami pasang surut. Perkembangan dalam sektor perusahaan juga diikuti kebutuhan dana yang besar sehingga perusahaan perusahaan harus mencari sumber dana guna melakukan operasionalnya. Kebutuhan sumber dana tersebut dapat dipenuhi dengan melakukan go public atau menjual sahamnya kepada masyarakat melalui pasar modal. Alternatif ini merupakan alternatif yang lebih mudah dan murah jika dibandingkan sumber pendanaan lain, misalnya melakukan peminjaman atau utang pada pihak lain. Pasar modal merupakan tempat bertemunya para pemodal dan pencari modal. Pasar modal yang ada di Indonesia merupakan pasar yang sedang berkembang, yang dalam perkembangannya sangat rentan terhadap kondisi makroekonomi secara umum.

Risiko tingkat suku bunga dan nilai tukar mata uang merupakan dua faktor ekonomi dan keuangan yang secara signifikan mempengaruhi nilai saham. Tingkat suku bunga secara tidak langsung mempengaruhi nilai dari harga saham. Kenaikan suku bunga berpengaruh negatif terhadap nilai aset dari peningkatan tingkat pengembalian (return) yang diperlukan. Selain itu, tingkat suku bunga yang tinggi menyebabkan investor mengubah struktur / investasi dari pasar modal menuju pasar surat-surat berharga yang merupakan pendapatan berjangka tetap (fixed-term income), seperti obligasi pemerintah. Sebaliknya, penurunan tingkat suku bunga menyebabkan peningkatan nilai pada saat sekarang dari dividen masa depan. Tingkat suku bunga dianggap sebagai salah satu penentu paling signifikan dari harga saham.

Menurut Kasmir (2015) Bunga bank dapat diartikan sebagai "Balas jasa yang diberikan oleh bank berdasarkan prinsil konvensional kepada nasabah yang membeli atau menjual produknya. Bunga bagi bank juga dapat diartikan sebagai harga yang harus dibayar kepada nasabah (yang memiliki simpanan) dan harga yang harus dibayar oleh nasabah kepada bank (nasabah yang memperoleh pinjaman)." Faktorfaktor utama yang memengaruhi besar kecilnya penetapan suku bunga secara garis besar yaitu, kebutuhan dana, persaingan, kebijaksanaan pemerintah, target laba yang diinginkan, jangka waktu, kualitas jaminan, reputasi perusahaan, produk yang kompetitif, hubungan baik, dan jaminan pihak ketiga.

Menurut Imamul Arifin, Gina Hadi (2009) Nilai tukar adalah "Harga suatu mata uang terhadap mata uang lainnya." Nilai tukar (kurs) yaitu pembayaran internasional yang memerlukan pertukaran mata uang suatu negara dengan mata uang negara lain dapat dilakukan dengan banyak cara, tetapi pada dasarnya ini meliputi pertukaran mata uang diantara pihak yang memiliki suatu mata uang dan membutuhkan mata uang lain.

Kenaikan harga valuta asing (artinya, kenaikan nilai tukar) disebut depresiasi mata uang dalam negeri. Mata uang asing menjadi lebih mahal; oleh karenanya, nilai relatif dari mata uang dalam negeri menurun. Jatuhnya harga mata uang asing (artinya, jatuhnya nilai tukar) merupakan apresiasi dari mata uang dalam negeri. Mata uang asing menjadi lebih murah; karenanya, nilai relatif mata uang dalam negeri naik.

Yang menyebabkan nilai tukar berubah adalah perubahan pada permintaan atau penawaran di pasar valuta asing. Segala sesuatu yang merubah kurva permintaan dollar ke kanan atau penawaran dollar ke kiri menyebabkan apresiasi dollar. Ini sesungguhnya tidak lain dari perumusan ulang hukum penawaran dan permintaan, yang diberlakukan untuk pasar mata uang asing.

Ada banyak sebab yang membuat pergeseran pada permintaan dan penawaran yang mengakibatkan perubahan nilai tukar yang sifatnya sementara dan sebagian lagi bersifat persisten; yaitu, kenaikan harga domestik produk ekspor, kenaikan harga luar negeri produk impor, perubahan tingkat harga keseluruhan, perubahan tingkat harga dalam persentase yang sama dikedua negara, perubahan tingkat harga hanya disatu 
negara, inflasi dengan tingkat yang berbeda, arus modal dan perubahan - perubahan struktural.

Kita tahu bahwa dollar AS sesungguhnya seperti "barang". Harganya ditentukan oleh besarnya permintaan dan penawaran terbatas. Datangnya penawaran berasal dari hasil devisa negara. Dari masuknya dana - dana asing ke Indonesia, baik itu melalui penanaman modal langsung ke proyek - proyek maupun melalui pasar uang dan modal. Dollar AS juga bisa diperoleh melalui aktivitas pariwisata ataupun hasil ekspor. Dan banyaknya permintaan terhadap dollar AS dikarenakan adanya kalangan yang mesti membayar utang, ada kalangan yang mesti membayar barang impor. Ada juga penyebab lain, termasuk spekulasi. Namun, salah satu yang terkait dengan pasar saham adalah keluarnya investor asing dari pasar saham. Mereka menjual sahamnya. Lalu hasil penjualan saham itu ditukarkan ke dollar AS dan kemudian dibawa pulang ke negaranya. Jadi, dengan kata lain, ketika investor asing melepas saham, berdampak pada penurunan indeks. Lalu hasil jualan saham dibelikan dollar AS. Itu salah satu penyebabnya indeks harga saham turun dan nilai rupiah juga turun.

Jika investor menginginkan keuntungan perusahaan meningkat, maka perusahaan menjadi lebih bernilai dan harga sahamnya akan naik. Pengaruh semacam ini menyebabkan harga saham bergerak mengikuti siklus bisnis, harganya tinggi jika laba sekarangnya tinggi dan harganya rendah jika laba sekarangnya rendah. Hal tersebut juga menyebabkan harga - harga saham bervariasi mengikuti faktor faktor yang mempengaruhi harapan terhadap keuntungan dimasa datang. Pengumuman tentang anggaran pertahanan yang baru, perubahan nilai tukar mata uang, atau perubahan kompleksitas politik semuanya dapat mempengaruhi harapan mengenai keuntungan dan dengan demikian mempengaruhi juga harga-harga saham.

Berdasarkan uraian diatas, maka peneliti tertarik untuk mengangkat permasalahan tersebut untuk dilakukannya penelitian dengan judul "Pengaruh Perubahan Tingkat Suku Bunga Bank Indonesia dan Perubahan Nilai Tukar Rupiah Pada US Dollar Terhadap Harga Saham - saham LQ45 di Bursa Efek Indonesia".

\section{B. Rumusan Masalah}

1. Apakah ada pengaruh perubahan antara tingkat suku bunga bank Indonesia terhadap harga saham - saham LQ45 di Bursa Efek Indonesia Tahun 2009 - 2015?

2. Apakah ada pengaruh perubahan antara nilai tukar rupiah pada US Dollar terhadap harga saham - saham LQ45 di Bursa Efek Indonesia Tahun 2009 - 2015?

3. Apakah ada pengaruh perubahan antara tingkat suku bunga bank Indonesia dan nilai tukar rupiah pada US Dollar terhadap harga saham - saham LQ45 di Bursa Efek Indonesia Tahun 2009 - 2015?

Kerangka berpikir atau kerangka konsep adalah berbagai teori yang telah dikumpulkan pada landasan teori dan telah diuraikan harus dapat menghasilkan beberapa konsep. Apabila konsep-konsep tersebut dihubungkan satu sama lain, akan memberikan suatu gambaran atau suatu fenomena. Untuk lebih jelas, kerangka berpikir menggunakan diagram atau skema untuk menggambarkannya. Maka kerangka berpikirnya adalah sebagai berikut. 


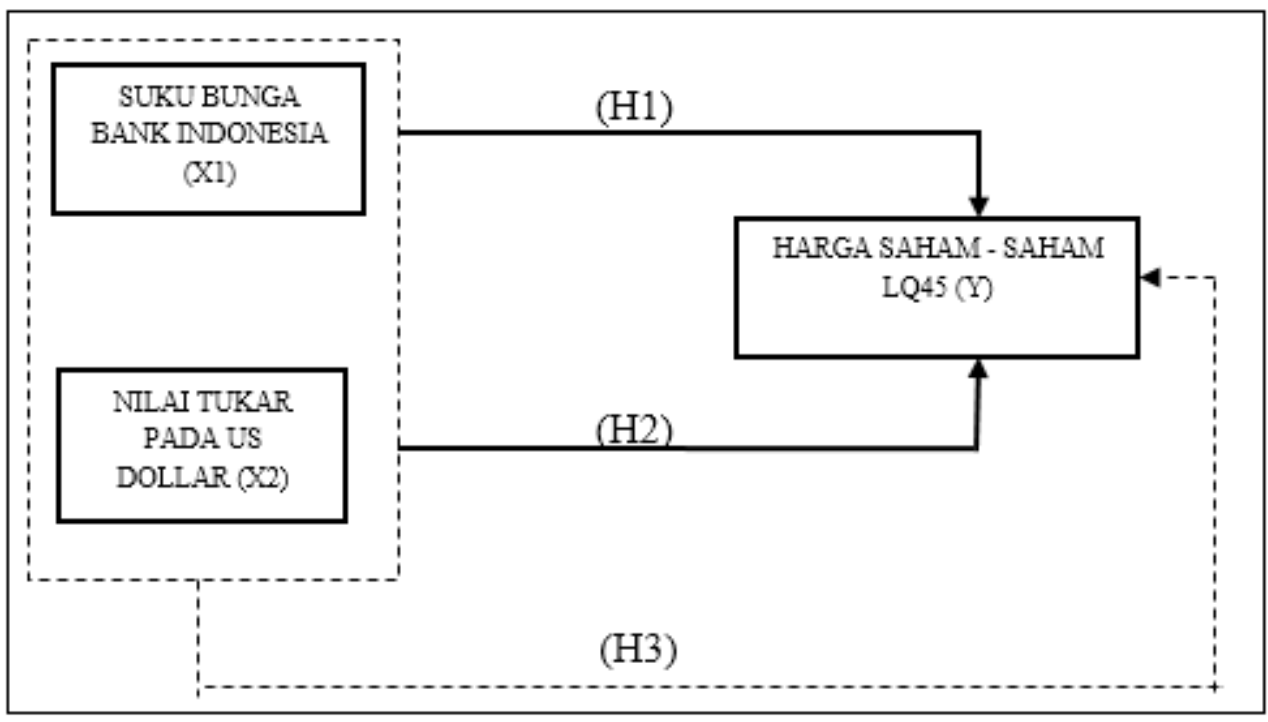

\section{Metedologi Penelitian}

\section{Populasi Dan Sampel}

Populasi yang digunakan dalam penelitian ini adalah seluruh perusahaan yang sahamnya tergabung dalam indeks LQ45 di BEI selama periode penelitian 2009 sampai dengan 2015. Sampel pada penelitian ini adalah perusahaan yang sahamnya tergabung dalam indeks LQ45 di BEl yang dipilih dengan metode purposive sampling. Kriteria pemilihan sampel penelitian yaitu perusahaan yang aktif tercatat / terdaftar sebanyak empat belas (14) kali secara berturut - turut di Indeks LQ45 selama periode penelitian $2009-2015$ atau dapat dilihat pada tabel berikut

\begin{tabular}{lll}
\hline No & Kriteria & $\begin{array}{l}\text { Jumlah } \\
\text { Sampel }\end{array}$ \\
\hline 1 & $\begin{array}{l}\text { Perusahaan yang terdaftar pada indeks LQ- } \\
45 \text { di BEl }\end{array}$ & \\
& & \\
\hline 2 & $\begin{array}{l}\text { Perusahaan yang tidak terdaftar sebanyak 14 } \\
\text { kali berturut }- \text { turut pada periode } \\
\text { pengamatan } 2009-2015\end{array}$ & \\
\hline & Jumlah sampel penelitian & 20
\end{tabular}

Jumlah sampel yang masuk kriteria penelitian adalah sebanyak 20 perusahaan yang terdaftar pada indeks LQ45.

\section{Teknik Pengumpulan Data}

Metode pengumpulan data yang digunakan dalam penelitian ini adalah sebagai berikut

\section{a. Riset Perpustakaan}

Metode ini dilakukan dengan cara mempelajari buku - buku ilmiah, informasi website dan jurnal ilmiah yang sesuai dengan penelitian dan dapat digunakan sebagai pendukung landasan teori. 


\section{b. Riset Lapangan}

Metode ini dilakukan dengan cara melakukan penelitian di yang beralamat di Jl. Jend. Sudirman Kav. 52-53 Jakarta 12190 untuk mendapatkan laporan indeks LQ45 di Bursa Efek Indonesia.

\section{Metode Analisis Data}

Metode analisis data disini merupakan jenis metode yang penulis data untuk menguji seluruh variabel-variabel dalam penelitian dengan data - data yang penulis dapatkan dari berbagai macam sumber. Dengan melakukan analisis data maka metode analisis yang akan digunakan adalah metode kuantitatif yang dinamakan metode tradisional karena metode ini sudah cukup lama digunakan sehingga sudah mentradisi sebagian metode penelitian. Metode ini pun disebut positivistic karena berlandaskan pada filsafat positivisme, disebut pula sebagai metode ilmiah karena telah memenuhi kaidah - kaidah ilmiah yaitu konkrit, objektif, terukur, rasional, dan sistematis. Dan disebut juga dengan metode discovery karena metode ini dapat ditemukan dan dikembangkan berbagai iptek baru serta dikatakan metode kuantitatif karena data penelitian berupa angka - angka dan analisis menggunakan statistik. (Sugiyono, 2009:7)

Metode analisis yang digunakan dalam penelitian ini adalah menggunakan analisis statistik melalui pendekatan Uji Asumsi Klasik, Uji Regresi Linier Berganda, Uji Koefisien Korelasi, Uji Koefisien Determinasi, Uji Parsial T dan Uji Simultan F dan selanjutnya akan dianalisis hasil regresi tersebut.

\section{Analisis Deskriptif}

Analisis deskriptif digunakan untuk menggambarkan variabel - variabel yang ada didalam penelitian ini. Pengukuran yang digunakan mencakup nilai rata - rata (mean), minimum dan maksimum yang disajikan dalam tabel numeric yang dihasilkan dari pengolahan data yang menggunakan SPSS. Statistik deskriptif adalah statistik yang digunakan untuk menganalisis data dengan cara mendeskripsikan atau menggambarkan data yang telah terkumpul sebagaimana adanya tanpa bermaksud membuat kesimpulan yang berlaku untuk umum atau generalisasi. (Sugiyono, 2011:147)

\section{Uji Asumsi klasik}

\section{a. Uji Normalitas}

Analisis normalitas bertujuan untuk menguji apakah dalam model regresi variabel dependen dan variabel independen keduanya mempunyai distribusi normal atau tidak. Digunakan untuk menguji apakah data tersebut normal atau tidak. Dasar pengambilan keputusan yaitu jika probabilitas lebih besar dari 0,05 maka Ho diterima yang berarti variabel berdistribusi normal jika probabilitas kurang dari 0,05 maka Ho ditolak yang berarti variabel tidak berdistribusi normal. (Santoso, 2003:393)

\section{b. Uji Multikolinieritas}

Salah satu asumsi klasik adalah tidak terjadi multikol diantara variabel independen yang ada dalam satu model dalam bentuk model regresi linier berganda hendaknya dihindari terjadinya multikolinier. Multikolinier berarti ada hubungan linier yang sempurna atau pasti diantara beberapa atau semua variabel penjelas. Apabila sebagian atau seluruh variabel independen berkorelasi kuat maka terjadi multikolinier. Konsekuensi terjadinya multikolinieritas adalah koefisien korelasi variabel tidak tertentu dan kesalahan 
menjadi sangat besar atau tidak terhingga. Dalam menentukan ada atau tidaknya multikolinieritas dapat menggunakan beberapa cara yaitu dengan :

1) Nilai tolerance adalah besarannya tingkat kesalahan yang dibenarkan secara statistik $(\alpha)$.

2) Nilai variance inflation factor (VIF) adalah faktor inflasi penyimpangan baku kuadrat.

Nilai tolerance $(\alpha)$ dan variance inflation factor (VIF) dapat dicari dengan menggabungkan kedua nilai tersebut sebagai berikut :

1) Besar nilai tolerance $(\alpha): \alpha=1 / \mathrm{VIF}$

2) Besar nilai variance inflation factor (VIF) : VIF $=1 / \alpha$

Apabila nilai tolerance value lebih tinggi dari pada 0.10 atau VIF lebih kecil dari pada 10 maka dapat disimpulkan tidak terjadi multikolinieritas atau bisa dibilang objektif dan dapat dipercaya.

\section{c. Uji Heterokedastisitas}

Penyimpangan asumsi klasik ini adalah adanya Heterokedastisitas, artinya varian variabel dalam model tidak sama. Konsekuensi adanya Heterokedastisitas dalam model regresi adalah penaksir yang diperoleh tidak efisien, baik dalam sampel kecil maupun besar, walaupun penaksir yang diperoleh menggambarkan populasinya dalam arti tidak bias. Bertambahnya sampel yang digunakan akan mendekati nilai sebenarnya (konsisten). Hal ini disebabkan oleh varian yang tidak efisien. Untuk mendeteksi ada tidaknya Heterokedastisitas dapat dilakukan dengan melihat plot gambar Scatterplot. Dan regresi yang tidak terjadi heterokedastisitas jika :

1) Titik-titik data menyebar diatas dan dibawah atau sekitar angka 0.

2) Titik-titik data tidak mengumpul hanya diatas atau dibawah saja.

3) Penyebaran titik - titik data tidak boleh membentuk bola bergelombang melebar kemudian menyempit kembali.

4) Penyebaran titik - titik tidak berpola.

\section{d. Uji Autokorelasi}

Analisis autokorelasi bertujuan untuk menguji apakah dalam suatu model regresi linear ada korelasi antara kesalahan pengganggu pada periode $t$ dengan kesalahan pada periode t-1 (sebelumnya). Salah satu ukuran dalam menentukan ada tidaknya masalah autokorelasi dengan uji Durbin-Waston (DW) dengan ketentuan sebagai berikut :

1) Terjadi autokorelasi positif, jika nilai DW dibawah -2 (DW<-2)

2) Tidak terjadi autokorelasi, jika nilai DW berada diantara -2 dan +2 atau $-2<$ $\mathrm{DW}<+2$

3) Terjadi autokorelasi, jika nilai DW diatas +2 atau DW $>+2$

\section{Uji Hipotesis}

\section{a. Uji Regresi Linear Berganda}

Analisis regresi linear berganda adalah hubungan secara linear antara dua variabel independen dengan variabel dependen. Analisis ini untuk mengetahui arah hubungan antara variabel independen dengan variabel dependen apakah masing-masing veriabel independen berhubungan positif atau negatif dengan untuk memprediksi nilai dari variabel dependen apabila nilai variabel independen mengalami kenaikan atau penurunan. Data yang digunakan biasanya berskala interval atau rasio.

Analisis regresi berganda dalam penelitian ini digunakan untuk mengetahui pengaruh tingkat suku bunga dan nilai tukar rupiah pada US 
Dollar mempunyai pengaruh terhadap harga saham-saham LQ-45. Sebelum peneliti melakukan analisis regresi berganda peneliti melakukan uji asumsi klasik. Berikut rumusan atau model dari regresi linear berganda :

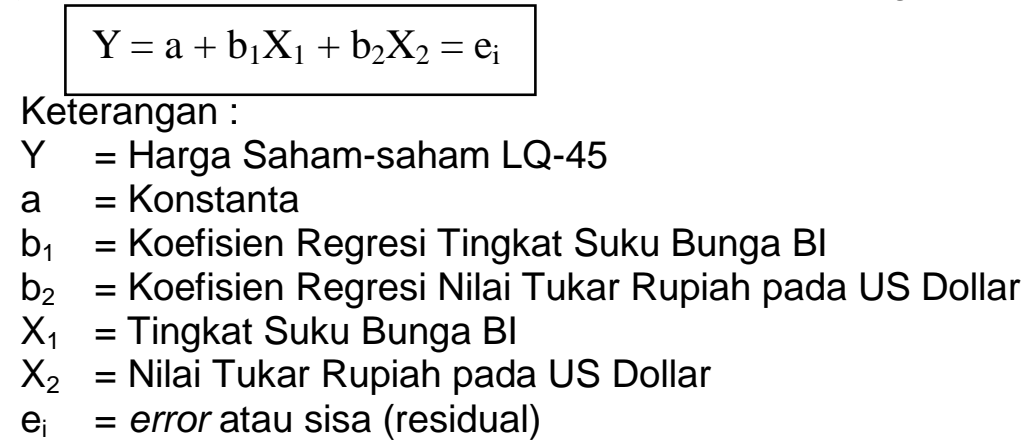

\section{b. Koefisien Determinasi}

Koefisien determinasi $\left(R^{2}\right)$ bertujuan mengukur besarnya presentase variabel $X$ terhadap $Y$. Jika nilai $R^{2}$ sebesar 1 , berarti fluktuasi variabel dependen seluruhnya dapat dijelaskan oleh variabel independen dan tidak ada faktor lain yang menyebabkan fluktuasi variabel dependen. Jika nilai $R^{2}$ berkisar 0 sampai 1 berarti semakin kuat kemampuan variabel independen dapat menjelaskan fluktuasi variabel dependen.

Rumus yang digunakan adalah sebagai berikut :

$$
\begin{aligned}
& \text { Dimana : } \\
& \text { Kd }=\text { Koefi } \\
& R^{2}=\text { Kuadrat Koefisien Korelasi }
\end{aligned}
$$

\section{c. Uji Parsial (Uji t)}

Uji t digunakan untuk mengetahui ada atau tidaknya pengaruh masingmasing variabel independen secara individu terhadap variabel dependen yang diuji pada tingkat signifikan 0,05 . Uji t bertujuan untuk mengetahui apakah variabel - variabel bebas yang digunakan dalam model persamaan regresi.

Dalam penelitian ini uji t yang digunakan untuk melihat pengaruh perubahan tingkat suku bunga bank Indonesia dan nilai tukar rupiah pada US Dollar sebagai variabel $X$ terhadap harga saham - saham LQ45 sebagai variabel $Y$, dengan kriteria sebagai berikut :

Jika nilai $\mathrm{t}$ hitung $\leq \mathrm{t}$ tabel Ho diterima, $\mathrm{HI}$ ditolak.

Jika nilai t hitung $\geq \mathrm{t}$ tabel Ho ditolak, $\mathrm{HI}$ diterima.

Intepretasi tingkat signifikan adalah :

1) Apabila t hitung $<t$ tabel pada taraf signifikan $5 \%$ berarti hubungan antar variabel signifikan.

2) Apabila $t$ hitung $>\mathrm{t}$ tabel pada taraf signifikan $5 \%$ berarti hubungan antar variabel tidak signifikan.

\section{d. Uji Simultan (Uji f)}

Uji $f$ bertujuan mengetahui variabel - variabel apakah variabel bebas yang digunakan dalam bentuk model regresi secara bersama - sama yang mampu menjelaskan variabel terikatnya. Uji ini bisa disebut juga uji global.

Uji statistik $f$ pada dasarnya untuk mengetahui apakah semua variabel bebas yang di masukan dalam model mempunyai pengaruh secara bersama-sama terhadap variabel terikat dan mengetahui apakah 
semua variabel bebas memiliki koefisien regresi sama dengan nol. (Suharyadi dan Purwanto, 2004:55)

Kriteria penerimaan dan penolakan hipotesis uji f sebagai berikut :

Jika f hitung $>\mathrm{f}$ tabel, maka Ho ditolak dan HI diterima.

Jika f hitung $<f$ tabel, maka Ho diterima dan HI ditolak.

Hasil uji $f$ pada output SPSS dapat dilihat pada tabel ANOVA. Untuk mengetahui variabel - variabel independen secara simultan mempengaruhi.

\section{Hasil Penelitian Dan Pembahasan Analisis Deskriptif}

Analisis deskriptif (Descriptive) digunakan untuk penggambaran tentang statistik data seperti nilai rata - rata (mean), nilai minimum dan maksimum, standar deviasi, dan lain - lain yang akan disajikan dalam bentuk tabel numeric. Adapun hasil dari uji statistik deskriptif terlihat pada Tabel berikut :

(Sumber : Data yang Diolah dengan Program SPSS Versi 24)

Dari hasil analisis deskriptif pada Tabel diatas, diperoleh informasi mengenai nilai minimum, nilai maksimum, rata - rata, dan standar deviasi tiap variabel penelitian.

Nilai maksimum Suku Bunga BI sebesar 5,77 persen merupakan nilai pada tahun 2012, sedangkan nilai maksimum sebesar 7,54 persen terjadi pada tahun 2014. Pada

variabel nilai terendah sebesar Rp. 8.779,49 adalah Nilai Tukar Rupiah pada US Dollar tahun 2011, sedangkan nilai tertinggi sebesar Rp. 13.391,97 merupakan nilai pada tahun 2015. Variabel Harga Saham - saham LQ45 memiliki rentang nilai Rp. 260 hingga Rp. 50.750. Nilai terendah dimiliki oleh PT. Kalbe Farma, Tbk pada tahun 2009, sedangkan nilai tertinggi dimiliki oleh PT. Indo Tambangraya Megah, Tbk pada tahun 2010.

\section{Uji Asumsi Klasik}

\section{a. Uji Normalitas}

Uji normalitas pada model regresi digunakan untuk menguji apakah nilai residual yang dihasilkan dari regresi terdistribusi secara normal atau tidak. Model regresi yang baik adalah yang memiliki nilai residual yang terdistribusi secara normal. Beberapa metode uji normalitas, yaitu dengan melihat penyebaran data pada sumber diagonal pada grafik Normal P-P Plot of regression standardized residual atau dengan uji One Sample Kolmogorov - Smirnov.

1) Uji One Sample Kolmogorov - Smirnov

Uji One Sample Kolmogorov - Smirnov digunakan untuk mengetahui distribusi data, apakah mengikuti distribusi normal, poisson, uniform, atau exponential. Dalam hal ini untuk mengetahui apakah distribusi residual terdistribusi normal atau tidak. Residual berdistribusi normal jika nilai signifikansi lebih dari 0,05. Berikut ini hasil dari uji One Sample Kolmogorov - Smirnov pada residual : 


\begin{tabular}{|ll|r|}
\hline & & \multicolumn{2}{|c|}{$\begin{array}{c}\text { Unstandardized } \\
\text { Residual }\end{array}$} \\
\hline N & $140^{\mathrm{c}}$ \\
Exponential parameter. ${ }^{\text {a,b }}$ & Mean & 10548,0040700 \\
Most Extreme Differences & Absolute &, 135 \\
& Positive &, 074 \\
Kolmogorov-Smirnov Z & Negative &,- 135 \\
Asymp. Sig. (2-tailed) & &, 954 \\
\end{tabular}

a. Test Distribution is Exponential.

b. Calculated from data.

c. There are 90 values outside the specified distribution range.

These values are skipped.

(Sumber : Data yang Diolah dengan Program SPSS Versi 24)

Pada Tabel terlihat bahwa uji normalitas terlihat hasilnya pada test keempat dan dengan mengikuti distribusi exponential. Besarnya nilai Kolmogorov - Smirnov adalah 0,954 dan nilai Asymp. Sig. (2-tailed) sebesar 0,323 dimana Asymp. Sig. (2-

tailed) lebih besar dari tingkat signifikansi sebesar $0,05(0,323>0,05)$. Karena nilai signifikansi lebih dari 0,05 , nilai residual terdistribusi dengan normal.

2) Metode Grafik

Uji normalitas residual dengan metode grafik, yaitu dengan melihat penyebaran data pada sumber diagonal pada grafik Normal P-P Plot of regression standardized residual. Sebagai dasar pengambilan keputusannya, jika titik - titik menyebar sekitar garis dan mengikuti garis diagonal, maka nilai residual tersebut telah normal.

Hasil grafik Normal P-P Plot pada penelitian ini terlihat seperti pada Gambar berikut :

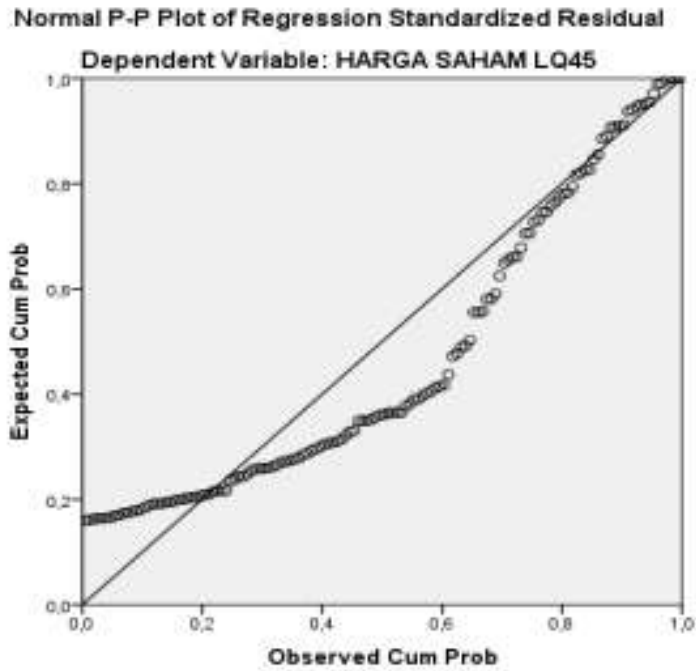

(Sumber : Data yang Diolah dengan Program SPSS Versi 24) 
Dari Gambar Grafik diatas dapat diketahui bahwa titik - titik menyebar sekitar garis dan mengikuti garis diagonal, maka nilai residual tersebut terdistribusi normal.

\section{b. Uji Multikolinieritas}

Uji multikolinieritas merupakan pengujian untuk mengetahui ada atau tidaknya korelasi yang signifikan antara variabel predictor atau independen dalam suatu model regresi berganda. Statistik uji yang sering digunakan untuk menguji gangguan multikolinieritas adalah Variance Inflation Factor (VIF) atau korelasi pearson antara variabel - variabel bebas. Kriteria pengambilan keputusan bila nilai tolerance $>0,10$ dan VIF $<10$ maka data tidak memiliki masalah multikolinieritas.

\begin{tabular}{|c|c|c|c|c|c|c|c|c|}
\hline & & \multicolumn{2}{|c|}{$\begin{array}{l}\text { Unstandardized } \\
\text { Coefficients }\end{array}$} & \multirow{2}{*}{$\begin{array}{c}\text { Standardized } \\
\text { Coefficients }\end{array}$} & \multirow[b]{2}{*}{ T } & \multirow[b]{2}{*}{ Sig. } & \multicolumn{2}{|c|}{$\begin{array}{l}\text { Collinearity } \\
\text { Statistics }\end{array}$} \\
\hline \multicolumn{2}{|c|}{ Model } & B & Std. Error & & & & Tolerance & VIF \\
\hline 1 & (Constant) & 14498,756 & 9759,937 & & 1,486 &, 140 & & \\
\hline & $\begin{array}{l}\text { SUKU BUNGA BI } \\
\text { NILAI TUKAR RUPIAH }\end{array}$ & $\begin{array}{r}-674,572 \\
, 002\end{array}$ & $\begin{array}{r}2218,285 \\
861\end{array}$ & $\begin{array}{r}-, 042 \\
, 000\end{array}$ & $\begin{array}{r}-, 304 \\
, 003\end{array}$ & $\begin{array}{l}762 \\
, 998\end{array}$ & $\begin{array}{l}382 \\
, 382\end{array}$ & $\begin{array}{l}2,621 \\
2,621\end{array}$ \\
\hline
\end{tabular}

a. Dependent Variable: HARGA SAHAM LQ45

Sumberi Data yang Diplah dengan Program SPSS Versi 24)

Tabel diatas menunjukkan bahwa nilai Tolerance kedua variabel lebih dari 0,10 dan VIF kurang dari 10, maka dapat diartikan bahwa tidak terjadi multikolinieritas antar variabel bebas.

\section{c. Uji Heteroskedastisitas}

Heteroskedastisitas adalah varian residual yang tidak sama pada semua pengamatan didalam model regresi. Regresi yang baik seharusnya tidak terjadi heteroskedastisitas. Macam - macam uji heteroskedastisitas antara lain adalah dengan uji koefisien korelasi Spearman's rho, melihat pola titik - titik pada grafik regresi Scatterplot, uji Park, dan uji Glejser. Untuk penelitian ini, peneliti akan menggunakan uji koefisien korelasi Spearman's rho, melihat pola titik - titik pada grafik regresi Scatterplot, dan uji Glejser.

1) Uji Koefisien Korelasi Spearman's rho

Pengujian heteroskedastisitas menggunakan teknik uji koefisien korelasi Spearman's rho, yaitu mengorelasikan variabel independen dengan residualnya. Pengujian menggunakan tingkat signifikansi 0,05 dengan uji 2 sisi. Jika korelasi antara variabel independen dengan residual didapat signifikansi lebih dari 0,05 maka dapat dikatakan bahwa tidak terjadi problem heteroskedastisitas.

Hasil dari uji koefisien korelasi Spearman's rho pada penelitian ini terlihat pada Tabel berikut : 


\begin{tabular}{|c|c|c|c|c|c|}
\hline & & & $\begin{array}{c}\text { SUKU } \\
\text { BUNGA BI }\end{array}$ & $\begin{array}{c}\text { NILAI } \\
\text { TUKAR } \\
\text { RUPIAH }\end{array}$ & $\begin{array}{c}\text { Unstandardized } \\
\text { Residual }\end{array}$ \\
\hline \multirow{9}{*}{$\begin{array}{l}\text { Spearman's } \\
\text { rho }\end{array}$} & \multirow[t]{3}{*}{ SUKU BUNGA BI } & Correlation Coefficient & 1,000 &, $536^{-}$ & ,056 \\
\hline & & Sig. (2-tailed) & &, 000 & 514 \\
\hline & & $N$ & 140 & 140 & 140 \\
\hline & \multirow[t]{3}{*}{ NILAI TUKAR RUPIAH } & Correlation Coefficient & $536^{-2}$ & 1,000 &, 060 \\
\hline & & Sig. (2-tailed) &, 000 & & 480 \\
\hline & & $\mathrm{N}$ & 140 & 140 & 140 \\
\hline & \multirow{3}{*}{$\begin{array}{l}\text { Unstandardized } \\
\text { Residual }\end{array}$} & Correlation Coefficient & 056 & 060 & 1,000 \\
\hline & & Sig. (2-tailed) & 514 & 480 & \\
\hline & & $\mathrm{N}$ & 140 & 140 & 140 \\
\hline
\end{tabular}

(Sumber : Data yang Didlah deogan Program SPSS Kersi 24)

Dari hasil Tabel diatas dapat dilihat bahwa korelasi antara variabel Suku Bunga BI dan Nilai Tukar Rupiah pada US Dollar dengan Unstandardized Residual memiliki nilai signifikansi (Sig 2 tailed) lebih dari 0,05 . Karena signifikansi lebih besar dari 0,05 dapat disimpulkan bahwa tidak terjadi masalah heteroskedastisitas.

\section{2) Metode Grafik Scatterplot}

Uji heteroskedastisitas merupakan pengujian asumsi residual dengan varian tidak konstan. Untuk mendeteksi gejala heteroskedastisitas dapat dilakukan dengan melihat grafik scatterplot. Apabila pada grafik ini menampilkan sebaran titik - titik data membentuk suatu pola (melebar, menyempit, dan bergelombang) maka telah

terjadi heteroskedastisitas. Dan apabila sebaran titik - titik data menyebar secara acak tidak berbentuk pola - pola tertentu, dan titik - titik menyebar diatas dan dibawah angka 0 pada sumbu $Y$, maka tidak terjadi heteroskedastisitas dan model regresi layak digunakan.

Untuk hasil pengujian heteroskedastisitas dengan metode grafik Scatterplot pada penelitian ini terlihat pada Gambar berikut :

Scatterplot

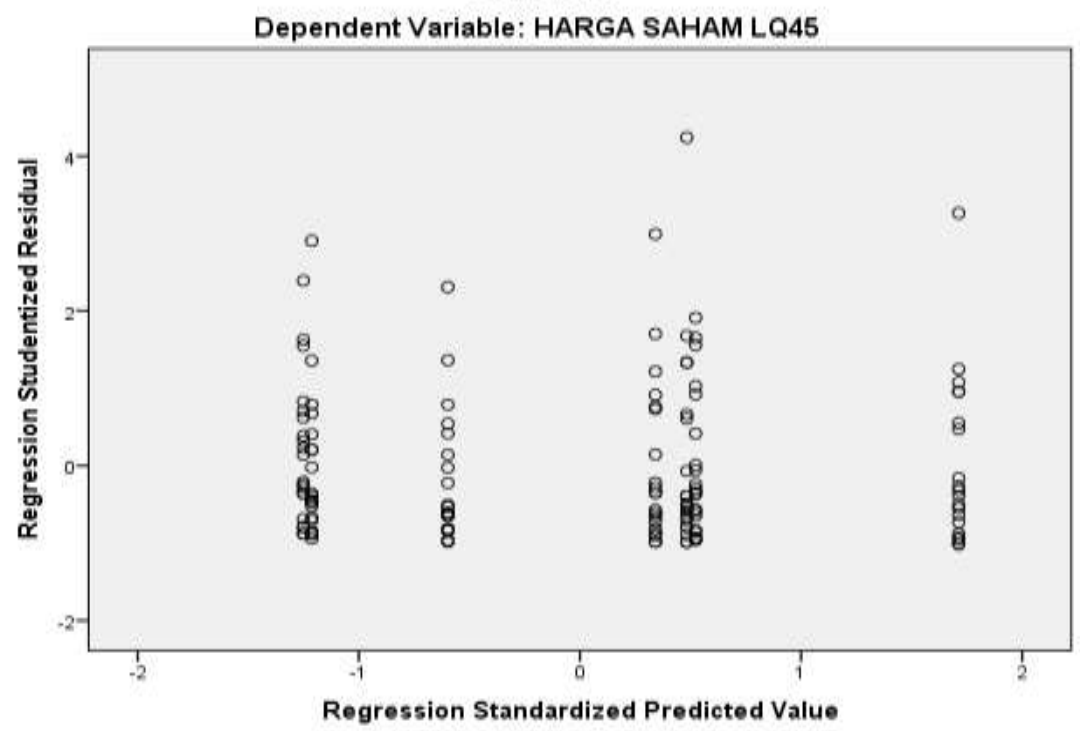

(Sumber : Data yang Diolah dengan Program SPSS Versi 24) 
Gambar diatas menunjukkan bahwa titik - titik pada grafik scatterplot menyebar diatas dan dibawah atau sekitar angka 0 pada sumbu $Y$, dan penyebaran titik - titik tidak membentuk bola bergelombang melebar kemudian menyempit kembali, maka dapat diartikan bahwa tidak terjadi heteroskedastisitas pada model regresi.

\section{3) Uji Glejser}

Uji Glejser dilakukan dengan cara meregresikan antara variabel independen dengan nilai absolute residualnya. Jika nilai signifikansi antara variabel independen dengan absolute residual lebih dari 0,05 maka tidak terjadi masalah heteroskedastisitas. Berikut hasil dari pengujian regresi variabel independen terhadap absolute residual dalam penelitian ini terlihat pada Tabel berikut:

\begin{tabular}{|c|c|c|c|c|c|c|}
\hline \multirow{2}{*}{\multicolumn{2}{|c|}{ Model }} & \multicolumn{2}{|c|}{$\begin{array}{c}\text { Unstandardized } \\
\text { Coefficients }\end{array}$} & \multirow{2}{*}{$\begin{array}{c}\text { Standardized } \\
\text { Coefficients } \\
\text { Beta }\end{array}$} & \multirow[b]{2}{*}{$\mathrm{T}$} & \multirow[b]{2}{*}{ Sig. } \\
\hline & & $\mathrm{B}$ & Std. Error & & & \\
\hline \multirow[t]{3}{*}{1} & (Constant) & 12477,167 & 5963,252 & & 2,092 &, 038 \\
\hline & SUKU BUNGA BI & $-200,828$ & 1355,357 &,- 020 &,- 148 & ,882 \\
\hline & NILAI TUKAR RUPIAH &,- 341 &, 526 &,- 089 &,- 649 &, 517 \\
\hline
\end{tabular}

(Sumber : Data yang Diolah dengan Program SPSS Versi 24)

Dari hasil Tabel diatas dapat diketahui bahwa nilai signifikansi kedua variabel independen lebih dari 0,05. Dengan demikian dapat disimpulkan bahwa tidak terjadi masalah heteroskedastisitas pada model regresi.

\section{d. Uji Autokorelasi}

Autokorelasi merupakan korelasi antara anggota observasi yang disusun menurut waktu atau tempat. Model regresi yang baik seharusnya tidak terjadi autokorelasi. Metode pengujian menggunakan uji Durbin Watson (DW test).

Pengambilan keputusan pada uji Durbin - Watson sebagai berikut :

1) Terjadi autokorelasi positif, jika nilai DW dibawah -2 (DW <-2)

2) Tidak terjadi autokorelasi, jika nilai DW berada diantara -2 dan +2 atau $-2<\mathrm{DW}<+2$

3) Terjadi autokorelasi, jika nilai $\mathrm{DW}$ diatas +2 atau $\mathrm{DW}>+2$

Dalam penelitian ini autokorelasi terlihat pada Tabel sebagai berikut :

\begin{tabular}{|l|c|r|r|c|c|}
\hline Model & $\mathrm{R}$ & $\mathrm{R}$ Square & $\begin{array}{c}\text { Adjusted R } \\
\text { Square }\end{array}$ & $\begin{array}{c}\text { Std. Error of the } \\
\text { Estimate }\end{array}$ & $\begin{array}{c}\text { Durbin- } \\
\text { Watson }\end{array}$ \\
\hline 1 &, $042^{2}$ &, 002 &,- 013 & 9653,79477 &, 221 \\
\hline
\end{tabular}

a. Predictors: (Constant), NILAI TUKAR RUPIAH, SUKU BUNGA BI

b. Dependent Variable: HARGA SAHAM LQ45

(Sumber : Data yang Diolah dengan Program SPSS Versi 24)

Nilai DU dan DL dapat diperoleh dari tabel statistik Durbin - Watson. Dengan $n=140$, dan $k=2$ didapat nilai $D L=1,6950$ dan $D U=1,7529$. Jadi nilai $4-\mathrm{DU}=2,2471$ dan $4-\mathrm{DL}=2,305$. 
Dari Tabel 4.8 diatas dapat diketahui nilai Durbin - Watson sebesar 0,221 . Karena nilai DW berada diantara -2 dan +2 atau $-2<\mathrm{DW}<+2$, artinya tidak terjadi autokorelasi.

\section{e. Uji Hipotesis}

\section{a. Uji Regresi Linear Berganda}

Analisis regresi ini digunakan terutama untuk tujuan peramalan, dimana dalam model tersebut ada sebuah variabel dependen (terikat) dan variabel independen (bebas). Dalam hal ini digunakan regresi linear berganda karena akan menganalisis pengaruh dari beberapa variabel independen terhadap suatu variabel.

Setelah semua pengujian asumsi klasik disimpulkan bahwa model regresi dapat digunakan. Untuk mengetahui pengaruh koefisien variabel Suku Bunga Bank Indonesia (X1), Nilai Tukar Rupiah pada US Dollar (X2) terhadap Harga Saham - saham LQ45 (Y) maka langkah selanjutnya untuk analisis regresi sebagai berikut :

\begin{tabular}{|c|c|c|c|c|c|c|c|c|}
\hline & & \multicolumn{2}{|c|}{$\begin{array}{l}\text { Unstandardized } \\
\text { Coefficients }\end{array}$} & \multirow{2}{*}{$\begin{array}{c}\begin{array}{c}\text { Standardized } \\
\text { Coefficients }\end{array} \\
\text { Beta }\end{array}$} & \multirow[b]{2}{*}{$\mathrm{T}$} & \multirow[b]{2}{*}{ Sig. } & \multicolumn{2}{|c|}{$\begin{array}{l}\text { Collinearity } \\
\text { Statistics }\end{array}$} \\
\hline \multicolumn{2}{|c|}{ Model } & $\mathrm{B}$ & Std. Error & & & & Tolerance & VIF \\
\hline \multirow[t]{3}{*}{1} & (Constant) & 14498,756 & 9759,937 & & 1,486 &, 140 & & \\
\hline & SUKU BUNGA BI & $-674,572$ & 2218,285 &,- 042 &,- 304 & ,762 & ,382 & 2,621 \\
\hline & NILAPTUKAR RUPIAH & ,002 &, 861 &, 000 & ,003 & ,998 & ,382 & 2,621 \\
\hline
\end{tabular}

(Sumber : Data yang diolah dengan Program SPSS Versi 24)

i

I analisis pada Tabel diatas dapat dinyatakan dalam persamaan regresi linear berganda sebagai berikut :

$$
Y=14498,756+(-674,572) X_{1}-0,002 X_{2}
$$

Dimana :

$Y=$ Harga Saham - saham LQ45

$\mathrm{X}_{1}=$ Suku Bunga BI

$\mathrm{X}_{2}=$ Nilai Tukar Rupiah pada US Dollar

Persamaan regresi linear tersebut dapat di interprestasikan sebagai berikut :

1) Dari persamaan diatas diketahui konstanta sebesar 14498,756 menunjukkan bahwa jika variabel independen yaitu Suku Bunga BI dan Nilai Tukar Rupiah pada US Dollar bernilai 0 (nol), maka nilai Harga Saham - saham LQ45 sebesar 14498,756.

2) Koefisien regresi Suku Bunga BI bernilai -674,572 menyatakan bahwa setiap kali terjadi peningkatan sebesar 1 kali pada Tingkat Suku Bunga BI, maka akan terjadi penurunan pada Harga Saham LQ45 sebesar 674,572 secara negatif berarti Suku Bunga BI berjalan berlawanan dengan Harga Saham - saham LQ45. Dengan asumsi variabel lain tetap (variabel lain sama dengan nol).

3) Koefisien regresi Nilai Tukar Rupiah pada US Dollar bernilai 0,002 menyatakan bahwa setiap kali terjadi peningkatan sebesar 1 kali pada Nilai Tukar Rupiah pada US Dollar, maka akan terjadi peningkatan pada Harga Saham - saham LQ45 sebesar 0,002 secara positif berarti Nilai Tukar Rupiah pada US Dollar berjalan searah dengan Harga Saham - 
saham LQ45. Dengan asumsi variabel tetap (variabel lain sama dengan nol).

\section{b. Koefisien Determinasi}

Koefisien determinasi ( $R$ Square) menunjukkan seberapa besar variabel independen menjelaskan variabel dependennya. Nilai $R$ Square adalah antara 0 sampai dengan 1. Apabila nilai $R$ Square semakin mendekati 1, maka variabel - variabel independen memberikan semua informasi yang dibutuhkan untuk memprediksi varian - variabel independen. Sebaliknya, semakin kecil nilai $R$ Square, maka kemampuan variabel - variabel independen dalam menjelaskan variasi - variabel dependen semakin terbatas. Berikut hasil dari uji koefisien determinasi pada penelitian ini :

\begin{tabular}{|l|r|r|r|r|}
\hline $\begin{array}{l}\text { Berikut } \\
\text { hasil dari } \\
\text { uji } \\
\text { koefisien } \\
\text { Model }\end{array}$ & $\mathrm{R}$ & R Square & \multicolumn{1}{|c|}{$\begin{array}{l}\text { Adjusted R } \\
\text { Square }\end{array}$} & Std. Error of the Estimate \\
\hline 1 &, $042^{\mathrm{a}}$ &, 002 &,- 013 & 9653,79477 \\
\hline
\end{tabular}

a. Predictors: (Constant), NILAI TUKAR RUPIAH, SUKU BUNGA BI

b. Dependent Variable: HARGA SAHAM LQ45

(Sumber : Data yang Diolah dengan Program SPSS Versi 24)

Tabel diatas menunjukkan bahwa nilai koefisien determinasi (Adjusted $R$ Square) adalah $-0,013$ atau sebesar $-1,3 \%$ yang artinya bahwa harga saham - saham LQ45 tidak berpengaruh terhadap Suku Bunga Bank Indonesia dan Nilai Tukar Rupiah pada US Dollar karena dalam regresi linear berganda, koefisien determinasi memiliki nilai 0 sampai dengan 1.

\section{c. Uji Hipotesis Secara Parsial (Uji t)}

Uji ini dilakukan untuk mengetahui hubungan antara variabel - variabel independen terhadap variabel dependen secara parsial (individu), maka dilakukan uji t. Uji hipotesis secara parsial (uji t) pada dasarnya menunjukkan seberapa jauh pengaruh satu variabel independen secara individual menerangkan variabel independen. Cara pengambilan keputusan, berdasarkan signifikansinya adalah :

- Jika signifikansi > 0,05 maka Ho diterima

- Jika signifikansi < 0,05 maka Ho ditolak Atau dengan cara melihat $\mathrm{T}$ tabel sebagai berikut :

- Ho diterima jika t hitung $<\mathrm{t}$ tabel

- Ho ditolak jika t hitung > t tabel

Adapun hipotesis dalam penelitian adalah sebagai berikut :

$\mathrm{Ho}_{1}$ : Tidak ada pengaruh perubahan tingkat Suku Bunga Bank Indonesia terhadap Harga Saham - saham LQ45

$\mathrm{Ho}_{1}$ : Ada pengaruh perubahan tingkat Suku Bunga Bank Indonesia terhadap Harga Saham - saham LQ45

$\mathrm{Ho}_{2}$ : Tidak ada pengaruh perubahan Niai Tukar Rupiah pada US Dollar terhadap Harga Saham - saham LQ45

$\mathrm{Ho}_{2}$ : Ada pengaruh perubahan Nilai Tukar Rupiah pada US Dollar terhadap Harga Saham - saham LQ45

Diperoleh hasil uji hipotesis secara parsial Suku Bunga Bank Indonesia $\left(X_{1}\right)$ sebagai berikut : 


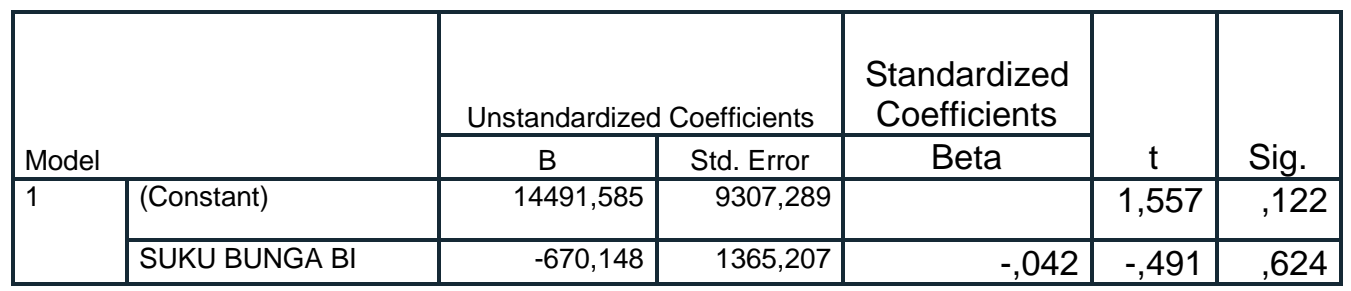

a. Dependent Variable: HARGA SAHAM LQ45

(Sumber : Data yang Diolah dengan Program SPSS Versi 24)

Terlihat pada Tabel diatas bahwa Suku Bunga $\mathrm{BI}$ memiliki $\mathrm{t}_{\text {hitung }}$ sebesar $-0,491$ sedangkan $t_{\text {tabel }}$ sebesar 1,97730 sehingga $t_{\text {hitung }}<t_{\text {tabel }}(-$ $0,491<1,97743)$, dan dengan tingkat signifikan variabel Suku Bunga BI sebesar 0,624 lebih besar dari taraf signifikan 0,05 $(0,624>0,05)$. Maka artinya $\mathrm{H} 0$ diterima dan $\mathrm{Ha}$ ditolak, sehingga dapat disimpukan bahwa secara parsial Suku Bunga BI tidak berpengaruh terhadap Harga Saham saham LQ45.

Diperoleh hasil uji hipotesis secara parsial Nilai Tukar Rupiah pada US Dollar $\left(\mathrm{X}_{2}\right)$ sebagai berikut :

\section{Hasil Uji Parsial (Uji t) Nilai Tukar Rupiah pada US Dollar $\left(\mathrm{X}_{2}\right)$} Coefficients $^{\mathrm{a}}$

\begin{tabular}{|c|c|c|c|c|c|c|}
\hline \multirow{2}{*}{\multicolumn{2}{|c|}{ Model }} & \multicolumn{2}{|c|}{$\begin{array}{c}\text { Unstandardized } \\
\text { Coefficients }\end{array}$} & \multirow{2}{*}{$\begin{array}{c}\begin{array}{c}\text { Standardized } \\
\text { Coefficients }\end{array} \\
\text { Beta }\end{array}$} & \multirow[b]{2}{*}{$\mathrm{T}$} & \multirow[b]{2}{*}{ Sig. } \\
\hline & & B & $\begin{array}{l}\text { Std. } \\
\text { Error }\end{array}$ & & & \\
\hline 1 & (Constant) & 12074,524 & $\begin{array}{r}5612,15 \\
1\end{array}$ & & 2,151 &, 033 \\
\hline & $\begin{array}{l}\text { NILAI TUKAR } \\
\text { RUPIAH }\end{array}$ &,- 204 &, 530 &,- 033 &,- 384 & ,701 \\
\hline
\end{tabular}

e a. Dependent Variable: HARGA SAHAM LQ45

$r$ (Sumber : Data yang Diolah dengan Program SPSS Versi 24)

lihat pada Tabel diatas bahwa Nilai Tukar Rupiah pada US Dollar memiliki $t_{\text {hitung }}$ sebesar $-0,384$ sedangkan $t_{\text {tabel }}$ sebesar 1,97730 sehingga $t_{\text {hitung }}<t_{\text {tabel }}$ $(-0,384<1,97743)$, dan dengan tingkat signifikan variabel Nilai Tukar Rupiah pada US Dollar sebesar 0,701 lebih besar dari taraf signifikan 0,05 $(0,701>0,05)$. Maka artinya HO diterima dan Ha ditolak, sehingga dapat disimpukan bahwa secara parsial Nilai Tukar Rupiah pada US Dollar tidak berpengaruh terhadap Harga Saham - saham LQ45.

Hasilnya :

- $\mathrm{Ha}_{1}$ : Tidak ada pengaruh perubahan tingkat Suku Bunga Bank Indonesia terhadap Harga Saham - saham LQ45

- $\mathrm{Ha}_{2}$ : Tidak ada pengaruh perubahan Nilai Tukar Rupiah pada US Dollar terhadap Harga Saham - saham LQ45

\section{d. Uji Hipotesis Secara Simultan (Uji F)}

Uji ini dilakukan untuk mengetahui apakah semua variabel independen dalam model regresi ini mempunyai pengaruh signifikan secara simultan atau tidak terhadap variabel dependen dilakukan uji F. Uji statistik F pada dasarnya menunjukkan apakah semua variabel independen yang 
dimasukkan dalam model regresi mempunyai pengaruh secara bersama sama terhadap variabel dependen.

Kriteria uji hipotesa yang digunakan adalah :

- Jika signifikan penelitian < 0,05 maka HO ditolak dan Ha diterima

- Jika signifikan penelitian > 0,05 maka HO diterima dan Ha ditolak

Adapun Hipotesis dalam penelitian ini adalah sebagai berikut :

$\mathrm{HO}$ : Tidak ada pengaruh perubahan tingkat Suku Bunga Bank Indonesia dan perubahan Nilai Tukar Rupiah pada US Dollar terhadap Harga Saham - saham LQ45

$\mathrm{Ha}$ : Ada pengaruh perubahan tingkat Suku Bunga Bank Indonesia dan perubahan Nilai Tukar Rupiah pada US Dollar terhadap Harga Saham - saham LQ45

Atau dengan cara melihat t tabel sebagai berikut :

- Jika $\mathrm{F}$ hitung $<\mathrm{F}$ tabel, maka $\mathrm{HO}$ diterima

- Jika F hitung > F tabel, maka HO ditolak

\section{Hasil Uji Simultan (Uji F)} ANOVA $^{\mathrm{a}}$

\begin{tabular}{|c|c|c|c|c|c|c|}
\hline \multicolumn{2}{|c|}{ Model } & Sum of Squares & Df & Mean Square & $\mathrm{F}$ & Sig. \\
\hline \multirow{1}{*}{1} & Regression & 22294314,230 & 2 & 11147157,120 &, 120 &, $887^{\circ}$ \\
\cline { 2 - 7 } & & & & & \\
\cline { 2 - 7 } & Residual & 12767818230,000 & 137 & 93195753,530 & & \\
\cline { 2 - 7 } & Total & 12790112550,000 & 139 & & & \\
\hline
\end{tabular}

a. Dependent Variable: HARGA SAHAM LQ45

b. Predictors: (Constant), NILAI TUKAR RUPIAH, SUKU BUNGA BI

(Sumber : Data yang Diolah dengan Program SPSS Versi 24)

Pengujian secara simultan pengaruh perubahan tingkat Suku Bunga BI $\left(X_{1}\right)$ dan perubahan Nilai Tukar Rupiah pada US Dollar $\left(X_{2}\right)$ terhadap Harga Saham - saham LQ45 (Y). Berdasarkan Tabel 4.12 diatas dapat dilihat $F_{\text {hitung }}$ sebesar 0,120 sedangkan $F_{\text {tabel }}$ sebesar 3,06 sehingga $F_{\text {hitung }}<F_{\text {tabel }}(0,120<3,06)$ dengan tingkat signifikan 0,887 lebih besar dari taraf signifikan sebesar 0,05 $(0,887>0,05)$, maka artinya $\mathrm{HO}$ diterima dan Ha ditolak. Sehingga dapat disimpulkan bahwa variabel Suku Bunga BI dan Nilai Tukar Rupiah pada US Dollar secara simultan bersama - sama tidak berpengaruh terhadap Harga Saham - saham LQ45.

Hasilnya :

Tidak ada pengaruh perubahan tingkat Suku Bunga Bank Indonesia dan perubahan Nilai Tukar Rupiah pada US Dollar terhadap Harga Saham - saham LQ45.

\section{F. Kesimpulan}

Berdasarkan hasil penelitian maka diperoleh kesimpulan sebagai berikut :

1. Variabel Suku Bunga Bank Indonesia secara parsial tidak mempunyai pengaruh signifikan terhadap Harga Saham - saham LQ45 di Bursa Efek Indonesia selama periode 2009 sampai dengan 2015. 
2. Variabel Nilai Tukar Rupiah pada US Dollar secara parsial tidak mempunyai pengaruh signifikan terhadap Harga Saham - saham LQ45 di Bursa Efek Indonesia selama periode 2009 sampai dengan 2015.

3. Variabel Suku Bunga Bank Indonesia dan Nilai Tukar Rupiah pada US Dollar secara simultan bersama - sama tidak mempunyai pengaruh signifikan terhadap Harga Saham - saham LQ45 di Bursa Efek Indonesia selama periode 2009 sampai dengan 2015.

\section{G. Daftar Pustaka}

Aditya Novianto. "Analisis Pengaruh Nilai Tukar (KURS) Dollar Amerika / Rupiah (US\$/Rp), Tingkat Suku Bunga, Inflasi, Dan Jumlah Uang Beredar (M2) Terhadap Indeks Harga Saham Gabungan (IHSG) Di Bursa Efek Indonesia (BEI) Periode 1991.1-2010.6". Universitas Diponegoro : Semarang, 2011.

Anisya Nurul Pramitha Sari. "Pengaruh Tingkat Inflasi, Suku Bunga SBI, dan Nilai Tukar Rupiah Pada US Dollar Terhadap Pergerakan Indeks Harga Saham Gabungan Perusahaan Manufaktur Yang Terdaftar Pada Bursa Efek Indonesia Periode Tahun 2010-2013". Universitas Dian Nuswantoro : Semarang, 2015.

Appley, A. Lawrence dan Lee, Oey Liang. "Pengantar Manajemen". Salemba Empat : Jakarta, 2010.

Arifin, Imamul dan Hadi, Gina. "Membuka Cakrawala Ekonomi”. Grafindo : Bandung, 2009.

Athoillah Anton. "Dasar-dasar Manajemen”. CV. Pustaka Setia : Bandung, 2010.

Aurora, Tona dan Agus Riyadi. "Pengaruh Inflasi, Suku Bunga, dan Kurs Terhadap Indeks LQ-45 di Bursa Efek Indonesia (BEI) Periode Tahun 2007-2011". Jurnal Dinamika Manajemen. Vol.1 No.3. Hal 183-197. 2013.

Ayu Dek dan Luh Gede. "Pengaruh Suku Bunga SBI, Inflasi, dan Fundamental Perusahaan Terhadap Harga Saham Indeks LQ-45 di BEl". Vol.5 No.4 Hal. 2494-2500. Universitas Udayana : Bali, 2016.

Darmadji, Tjiptono dan Fakhruddin. "Pasar Modal di Indonesia Edisi Ketiga". Salemba Empat : Jakarta, 2012.

Fahmi Irham. “Analisis Laporan Keuangan Cetakan Kedua”. Alfabeta : Bandung, 2012.

Fahmi Irham. "Pengantar Manajemen Keuangan". Alfabeta : Bandung, 2013.

Fahmi, Irham dan Yovi, L. Hadi. "Teori Portofolio dan Analisis Investasi". Alfabeta : Bandung, 2011.

Gitman, Lawrence. "Principles of Manajerial Finance". United States : Pearson Addison Wesley, 2009.

Halim, Abdul dan Mamduh M. Hanafi. "Analisis Laporan Keuangan Edisi Empat”. UPP STIM YKPN : Yogyakarta, 2009.

Husnan Suad. "Dasar-dasar Teori Portofolio dan Analisis Sekuritas Edisi Keempat". UPP STIM YKPN : Yogyakarta, 2009.

Ismawati, Linna dan Hermawan Beni. "Pengaruh Kurs Mata Uang Rupiah Atas Dollar AS, Tingkat Suku Bunga Sertifikat Bank Indonesia Dan Tingkat Inflasi Terhadap Indeks Harga Saham Gabungan (IHSG) Pada Bursa Efek Indonesia (BEI)". Jurnal Ekono Insentif Kopwil4. Vol.7, No.2. 2013

Kasmir. "Analisis Laporan Keuangan". PT. Raja Grafindo Persada : Jakarta, 2009.

Kasmir. "Pengantar Manajemen Keuangan". Kencana Prenada Media Group : Jakarta, 2010.

Kasmir. "Dasar-dasar Perbankan Edisi Revisi 2014”. Rajawali Pers : Jakarta, 2015.

Kewal, Suramaya S. "Pengaruh Inflasi, Suku Bunga, Kurs, dan Pertumbuhan PDB Terhadap Indeks Harga Saham Gabungan". Sekolah Tinggi Ilmu Ekonomi Musi : Palembang, 2012.

Kuncoro, Mudrajad. "Mudah Memahami \& Menganalisis Indikator Ekonomi”. UPP STIM YKPN : Yogyakarta, 2013. 
Latumaerissa, Julius R. "Bank dan Lembaga Keuangan Lain". Salemba Empat : Jakarta, 2011.

Martono dan Agus Harjito. "Manajemen Keuangan (Edisi 3)". Ekonisia : Yogyakarta, 2010.

Kadim, A., \& Sunardi, N. (2018). Pengaruh Analisa Kesahatan dan Kebangkrutan Dengan Pendekatan ALtman Z-Score Terhadap Harga Saham Industri Konstruksi di Indonesia yang Listing di BEI Periode 2013-2017. Jurnal SEKURITAS (Saham, Ekonomi, Keuangan dan Investasi), 1(4).

Sunardi, N., \& Ula, L. N. R. (2017). Pengaruh BI Rate, Inflasi Dan Kurs Terhadap Indeks Harga Saham Gabungan (IHSG). Jurnal Sekuritas, 1(2), 27.

Sunardi, N. (2019). Kinerja Perusahan Pendekatan Du Pont System Terhadap Harga Dan Return Saham (Perusahaan yang tergabung dalam Industri Real Estate dan Properti yang terdaftar di Bursa Efek Indonesia Tahun 2011-2017). JIMF (Jurnal IImiah Manajemen Forkamma), 1(3).

Kadim, A. (2019, January). Pengaruh Mekanisme Good Corporate Governance Terhadap Kinerja Perusahaan dengan Likuiditas Sebagai Variabel Intervening Pada Perusahaan Manufaktur yang Terdaftar di Bursa Efek Indonesia Tahun 2012-2017. In PROCEEDINGS (Vol. 1, No. 1).

Priyatno, Duwi. "SPSS 22 Pengolah Data Terpraktis". Andi : Yogyakarta, 2014.

Santoso. "SPSS Mengolah Data Statistik Secara Profesional". PT. Elex Media Komputindo : Jakarta, 2003.

Sartono Agus. "Manajemen Keuangan Teori dan Aplikasi Edisi 4". BPFE- Yogyakarta : Yogyakarta, 2015.

Solihin Ismail. "Pengantar Manajemen". Erlangga : Jakarta, 2009.

Sugiyono. "Metode Penelitian Pendidikan Pendekatan Kuantitatif, Kualitatif, dan R\&D". ALFABETA : Bandung, 2011.

Suharyadi dan Purwanto. "Statistik Dasar". PT. Raja Grafindo Persada : Jakarta, 2004.

Sunariyah. "Pengantar Pengetahuan Pasar Modal Edisi Keenam". UPP STIM YKPN : Yogyakarta, 2011.

Sutrisno. "Manajemen Keuangan, Teori, Konsep, dan Aplikasi (8th ed.)". Ekonisia : Yogyakarta, 2012.

Tandelilin, Eduardus. "Portofolio dan Investasi Teori dan Aplikasi Edisi Pertama". KANISIUS : Yogyakarta, 2010.

Terry, George R. "Teori Manajemen”. Bina Aksara : Jakarta, 2010.

Terry, George R. dan Leslie, W. Rue. "Dasar-dasar Manajemen Cetakan Kesebelas". PT. Bumi Aksara : Jakarta, 2010.

http://www.bi.go.id/id/moneter/bi-rate/data/Default.aspx, data BI Rate, di unduh pada tanggal 13 Nopember 2016.

http://www.bi.go.id/id/moneter/informasi-kurs/transaksi-bi/Default.aspx, Kurs Transaksi $\mathrm{BI}$, diunduh pada tanggal 13 Nopember 2016. 